\title{
Regulation of glucose metabolism in T cells: new insight into the role of phosphoinositide 3-kinases
}

\author{
David K. Finlay ${ }^{1,2 *}$ \\ 'School of Biochemistry and Immunology, Trinity Biomedical Sciences Institute, Trinity College Dublin, Dublin, Ireland \\ 2 School of Pharmacy and Pharmaceutical Sciences, Trinity Biomedical Sciences Institute, Trinity College Dublin, Dublin, Ireland
}

\section{Edited by: \\ Klaus Okkenhaug, Babraham \\ Institute, UK}

\section{Reviewed by:}

Stephen Geoffrey Ward, University of Bath, UK

Lawrence Kane, University of

Pittsburgh School of Medicine, USA

\section{*Correspondence:}

David K. Finlay, School of Biochemistry and Immunology, Trinity Biomedical Sciences Institute, Trinity College, Dublin 2, Ireland.

e-mail: finlayd@tcd.ie
Naïve $T$ cells are relatively quiescent cells that only require energy to prevent atrophy and for survival and migration. However, in response to developmental or extrinsic cues $T$ cells can engage in rapid growth and robust proliferation, produce of a range of effector molecules and migrate through peripheral tissues. To meet the significantly increased metabolic demands of these activities, T cells switch from primarily metabolizing glucose to carbon dioxide through oxidative phosphorylation to utilizing glycolysis to convert glucose to lactate (termed aerobic glycolysis). This metabolic switch allows glucose to be used as a source of carbon to generate biosynthetic precursors for the production of protein, DNA, and phospholipids, and is crucial for T cells to meet metabolic demands. Phosphoinositide 3-kinases (PI3K) are a family of inositol lipid kinases linked with a broad range of cellular functions in T lymphocytes that include cell growth, proliferation, metabolism, differentiation, survival, and migration. Initial research described a critical role for PI3K signaling through Akt (also called protein kinase B) for the increased glucose uptake and glycolysis that accompanies $T$ cell activation. This review article relates this original research with more recent data and discusses the evidence for and against a role for $\mathrm{PI} 3 \mathrm{~K}$ in regulating the metabolic switch to aerobic glycolysis in T cells.

Keywords: PI3K, Glucose metabolism, Akt, T lymphocyte, aerobic glycolysis, c-Myc, PDK1

\section{PI3K IN T CELLS}

Class 1 phosphoinositide 3-kinases (PI3K), lipid kinases that phosphorylate phosphatidylinositol-(4,5)-bisphosphate $\left[\mathrm{PI}(4,5) \mathrm{P}_{2}\right]$ to generate the lipid signaling molecule phosphatidylinositol- $(3,4,5)$ trisphosphate $\left[\mathrm{PI}(3,4,5) \mathrm{P}_{3}\right]$, play a crucial role in many aspects of T cell biology (Okkenhaug and Vanhaesebroeck, 2003). Class 1 PI3Ks consist of a catalytic subunit, responsible for the lipid kinase activity, and an adapter subunit which links the catalytic subunit to upstream activating signals. They are subdivided into Class $1 \mathrm{~A} ; \mathrm{p} 110 \alpha, \beta$, or $\delta$ catalytic subunits coupled to $\mathrm{p} 85$ adapter subunits, and Class $1 \mathrm{~B} ; \mathrm{p} 110 \gamma$ catalytic subunit coupled to the p101 adapter protein. The p85 subunit couples Class 1A PI3Ks to docking sites created by tyrosine-kinase signaling while the Class IB p101 links the p110 $\gamma$ kinase with G-protein-coupled receptors (Vanhaesebroeck et al., 2010). The levels of the lipid signaling molecule $\mathrm{PI}(3,4,5) \mathrm{P}_{3}$ are coordinately regulated by both class 1 PI3Ks and by the action of $3^{\prime}$ and $5^{\prime}$ phosphatases PTEN and SHIP1 that dephosphorylate $\mathrm{PI}(3,4,5) \mathrm{P}_{3}$ to generate $\mathrm{PI}(4,5) \mathrm{P}_{2}$ and $\mathrm{PI}(3,4) \mathrm{P}_{2}$ respectively (Figure $\left.1 \mathbf{A}\right)$.

$\mathrm{PI}(3,4,5) \mathrm{P}_{3}$ is an important lipid signaling molecule in $\mathrm{T}$ cells, present at low levels in naïve $\mathrm{T}$ cells and elevated in response to signaling initiated by the $\mathrm{T}$ cell receptor (TCR) and various cytokine and chemokine receptors (Koyasu, 2003). Following TCR engagement by antigen presenting cells (APC) levels of $\mathrm{PI}(3,4,5) \mathrm{P}_{3}$ accumulate in the plasma membrane and are maintained for prolonged periods, requiring continual TCR engagement and activation of PI3K (Costello et al., 2002; Harriague and Bismuth, 2002; Huppa et al., 2003). Signals from costimulatory molecules such as CD28 are important for sustaining
$\mathrm{PI}(3,4,5) \mathrm{P}_{3}$ levels following TCR engagement but are not in themselves sufficient to stimulate $\mathrm{PI} 3 \mathrm{~K}$ as $\mathrm{PI}(3,4,5) \mathrm{P}_{3}$ levels are only induced when the TCR engages APC presenting cognate peptide antigen (Costello et al., 2002; Garcon et al., 2007). Other physiological stimuli that can stimulate $\mathrm{PI}(3,4,5) \mathrm{P}_{3}$ levels in $\mathrm{T}$ cells include cytokines and chemokines (Koyasu, 2003). While $\mathrm{PI}(3,4,5) \mathrm{P}_{3}$ levels are induced by a number of cytokines it should be noted that the potency of these different cytokines can vary, e.g., IL2 maintains high levels of $\mathrm{PI}(3,4,5) \mathrm{P}_{3}$ while IL15 maintains comparatively low levels (Cornish et al., 2006; Sinclair et al., 2008).

In the thymus, PI $3 \mathrm{~K} \delta$ and PI3K $\gamma$ are the major isoforms required in developing thymocytes. While deletion of PI3K $\delta$ or $\gamma$ individually does not have a pronounced effect on thymopoiesis, deletion or inactivation of both isoforms in developing $\mathrm{T}$ cells results in a block early in thymocyte development at the CD4 CD8 double negative (DN) stage (Sasaki et al., 2000; Okkenhaug et al., 2002; Webb et al., 2005; Swat et al., 2006; Ji et al., 2007). Negative regulation of $\mathrm{PI}(3,4,5) \mathrm{P}_{3}$ signaling is also important in developing thymocytes. Thus, deletion of PTEN in early thymocyte progenitors results in constitutive $\mathrm{PI}(3,4,5) \mathrm{P}_{3}$ signaling that leads to the development of T cell leukemia or lymphoma (Suzuki et al., 2001; Hagenbeek and Spits, 2008; Finlay etal., 2009). In contrast to developing thymocytes, in mature $\mathrm{T}$ cells $\mathrm{PI} 3 \mathrm{~K} \delta$ appears to be the major PI3K isoform responsible for promoting $\mathrm{PI}(3,4,5) \mathrm{P}_{3}$ signaling in activated $\mathrm{T}$ cells. Thus, a point mutation that makes $\mathrm{p} 110 \delta$ catalytically inactive (D910A) abolishes $\mathrm{PI}(3,4,5) \mathrm{P}_{3}$ signaling in activated T cell subsets (Okkenhaug et al., 2002, 2006; Macintyre et al., 2011). 


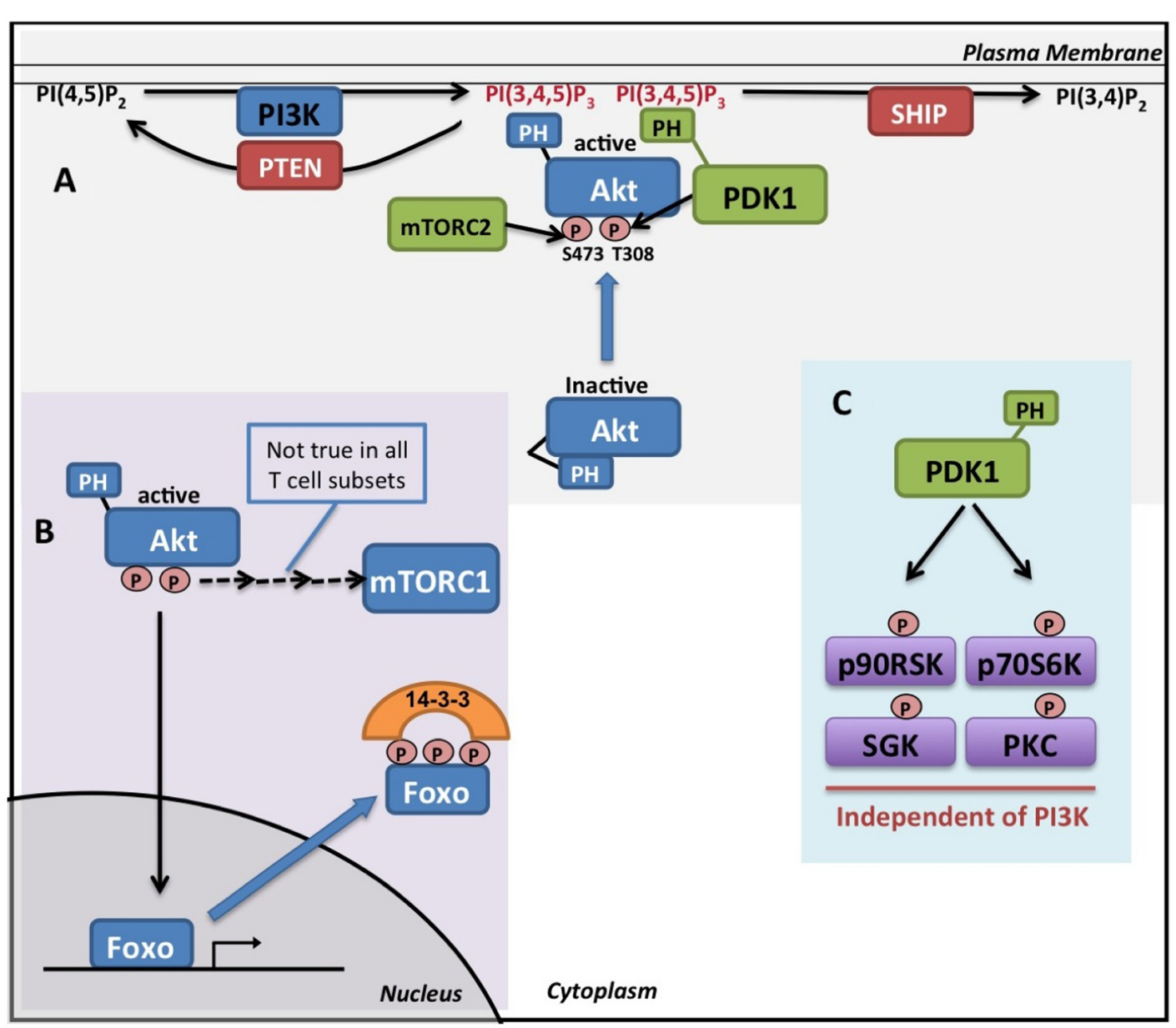

FIGURE 1 | PI3K and Akt signaling. (A) $\mathrm{PI}(4,5) \mathrm{P}_{2}$ is phosphorylated by Class $1 \mathrm{PI} K \mathrm{~K}$ isoforms generating the second messenger molecule $\mathrm{PI}(3,4,5) \mathrm{P}_{3}$. Levels of $\mathrm{PI}(3,4,5) \mathrm{P}_{3}$ are negatively regulated by the lipid phosphatases PTEN and SHIP. Binding of the PH domain of Akt to PI $(3,4,5) \mathrm{P}_{3}$ in the membrane results in a conformational change that allows for the phosphorylation of Akt on key residues(T308 and S473) by PDK1 and mTORC2. The recruitment of PDK1, via its PH domain, to the site of
$\mathrm{PI}(3,4,5) \mathrm{P}_{3}$ is required for efficient Akt activation. (B) Active Akt phosphorylates Foxo transcription factors on multiple sites resulting in their translocation to the cytoplasm where they are retained in complex with 14-3-3 proteins. mTORC1 can be activated downstream of Akt, though this does not occur in all T cell types. (C) PDK1 also phosphorylates and activates a number of other members of the AGC kinase family in a PI3K independent manner.

\section{PI3K SIGNALING}

$\mathrm{PI}(3,4,5) \mathrm{P}_{3}$ acts as a signaling molecule through its interaction with the pleckstrin homology $(\mathrm{PH})$ domains of a diverse array of signal transduction proteins. These proteins include Akt (also called PKB), Tec family kinases, and guanine-nucleotide-exchange proteins for Rho family GTPases. This interaction primarily controls the subcellular localization of $\mathrm{PH}$ domain containing proteins but can also control protein conformation and enzyme activity. Consider, for example, the activation of Akt, which is the best characterized $\mathrm{PI}(3,4,5) \mathrm{P}_{3}$ effector in $\mathrm{T}$ cells (for reviews Alessi and Cohen, 1998; Hanada et al., 2004; Cameron et al., 2007). The interaction of $\mathrm{PI}(3,4,5) \mathrm{P}_{3}$ with the $\mathrm{PH}$ domain of Akt stimulates its kinase activity by inducing a conformational change that allows Akt to be phosphorylated on threonine 308 and serine 473 by its upstream activating kinases phosphoinositide-dependent kinase 1 (PDK1) and mechanistic Target Of Rapamycin Complex 2 (mTORC2) respectively (Figure 1A; Calleja et al., 2007). PDK1 also contains a PH domain and co-localization of Akt and PDK1 to sites of $\mathrm{PI}(3,4,5) \mathrm{P}_{3}$ is required for efficient Akt activation (Bayascas et al., 2008; Waugh et al., 2009). Once activated, Akt phosphorylates a number of important signaling molecules including the Foxo transcription factors (Manning and Cantley, 2007). Foxo transcription factors localize to the nucleus where they promote the expression of target genes. Once phosphorylated by Akt, Foxos translocate into the cytoplasm where they are retained through their interaction with 14-3-3 proteins (Figure 1B; Coffer and Burgering, 2004; Burgering, 2008). PI3K/Akt signaling also activates the mTOR Complex 1 (mTORC1) in many cellular systems through multiple mechanisms (Laplante and Sabatini, 2009). mTORC1 is an important regulator of cellular metabolism that senses environmental cues such as nutrient availability and energy homeostasis (Delgoffe and Powell, 2009). However, it is now becoming apparent that mTORC1 activity is not universally dependent upon PI3K/Akt signaling in T cells. Thus, in activated 
CD8 cells, mTORC1 activity is not blocked by the disruption of PI3K/Akt signaling by various pharmacological and genetic strategies (unpublished data; Macintyre et al., 2011).

\section{MATCHING GLUCOSE METABOLISM TO METABOLIC DEMANDS}

While naïve $\mathrm{T}$ cells only require energy to prevent atrophy and for survival and migration, activated $\mathrm{T}$ cell subsets have a greatly increased metabolic demand as they engage in rapid growth and proliferation, and the production of cytokines and other effector molecules. It is crucial that activated $\mathrm{T}$ cells increase their metabolism to meet the biosynthetic needs of the $\mathrm{T}$ cell as it responds either to developmental or pathogenic cues. To achieve this $\mathrm{T}$ cells respond to extrinsic signals from antigen receptors and cytokines to up-regulate the surface expression of key nutrient receptors: amino acid transporters, the transferrin receptor, and glucose transporters (Fox et al., 2005a; Kelly et al., 2007; Jacobs et al., 2008). Additionally, T cells switch their glucose metabolism from oxidative phosphorylation to aerobic glycolysis; i.e., glucose is metabolized to produce lactate even though oxygen is readily available (Figure 2; Greiner et al., 1994). Aerobic glycolysis is an inefficient route to generating ATP, producing two molecules ATP per molecule of glucose compared to $>30$ molecules ATP per glucose generated by oxidative phosphorylation. Therefore, cells must be able to sustain high levels of glucose uptake and an elevated glycolytic flux to generate sufficient ATP. This is achieved by increasing the expression of the GLUT1 glucose transporter and certain rate limiting enzymes within the glycolytic pathway (Vander Heiden et al., 2009; Marko et al., 2010). However, the real advantage of switching from oxidative phosphorylation to glycolysis is that it allows glucose to be used as a source of carbon to generate nucleic acid, amino acids and phospholipids (Figure 2; Vander Heiden et al., 2009). The generation of these biosynthetic precursors is critical for cells engaging in rapid growth, proliferation, and the synthesis of effector molecules. Therefore, to facilitate their differentiation and function, activated $\mathrm{T}$ cells up-regulate the expression of GLUT1, increase glucose uptake, and activate the switch to aerobic glycolysis

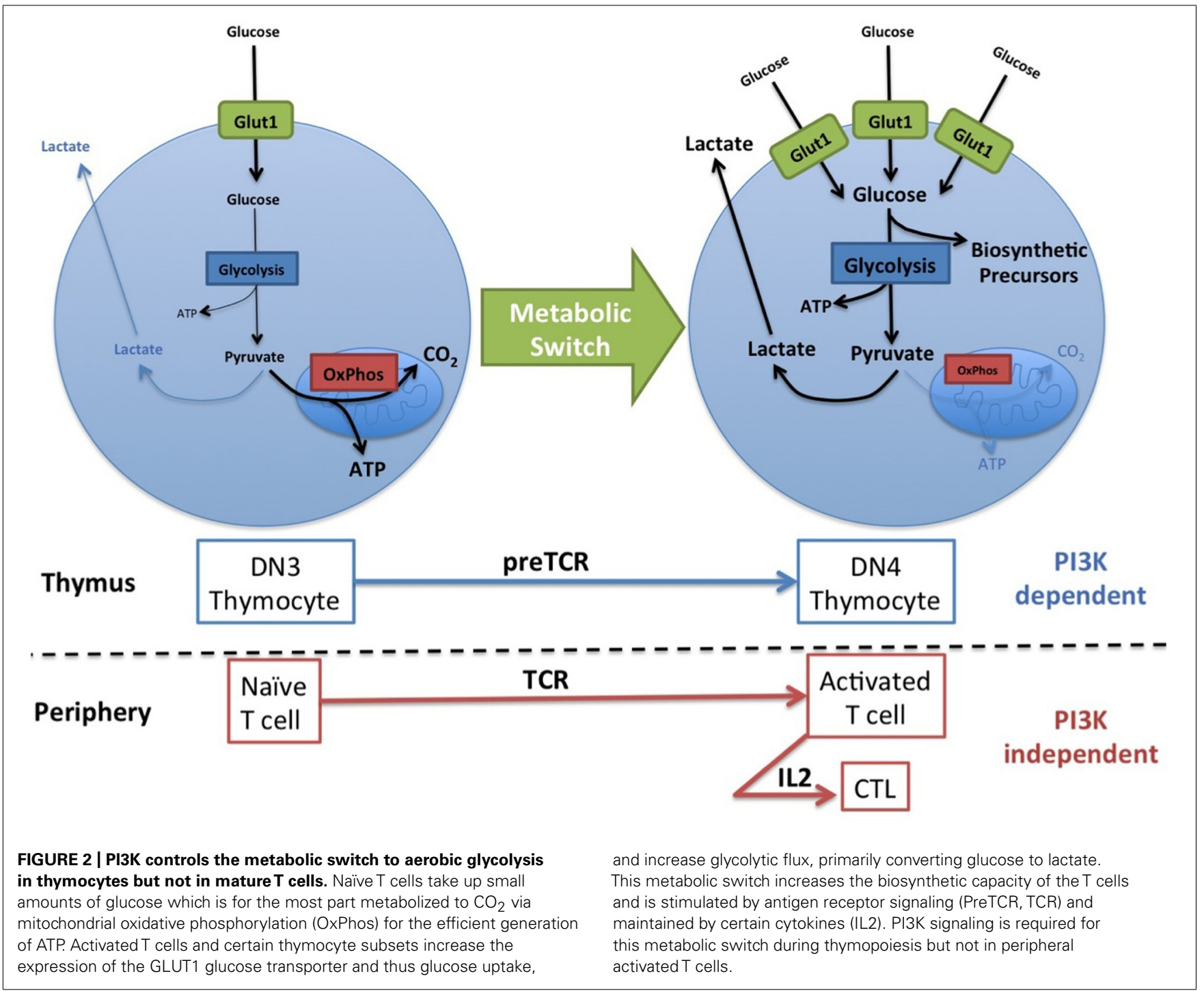


(Brand etal., 1984; Greiner et al., 1994; Frauwirth et al., 2002; Wofford et al., 2008).

\section{PI3K AND GLUCOSE METABOLISM IN THE THYMUS}

In the thymus discrete subpopulations, e.g., DN4 thymocytes, engage in rapid growth and robust proliferation. PI3K and Akt signaling is crucial in allowing these thymocyte subsets to match their metabolism with metabolic demands (Ciofani and ZunigaPflucker, 2005; Juntilla et al., 2007; Kelly et al., 2007; Finlay et al., 2010). Thus, mice lacking Akt or PDK1 or both PI3K $\delta$ and $\gamma$ isoforms during early thymopoiesis have a profound developmental block at the DN3/DN4 stage of T cell development(Hinton et al., 2004; Webb et al., 2005; Swat et al., 2006; Fayard et al., 2007; Juntilla et al., 2007; Mao et al., 2007). In the absence of PI3K/PDK1/Akt signaling DN4 thymocytes fail to up-regulate the expression of the glucose transporter, GLUT1, and also the expression of other key nutrient receptors for the uptake of amino acids (CD98, component of the L-amino acid transporter) and iron (transferrin receptor, CD71). Increased provision of these nutrients is a key requirement for these cells to meet the metabolic demands of rapid growth and proliferation and PI3K/PDK1/Akt deficient DN4 thymocytes that fail to do so atrophy and fail to develop (Juntilla et al., 2007; Kelly et al., 2007). Therefore, in T cells developing in the thymus, PI3K and Akt signaling is crucial to allow certain thymocyte subsets to match glucose metabolism with metabolic demands.

\section{PI3K AND GLUCOSE METABOLISM IN ACTIVATED T CELLS}

The metabolic switch to aerobic glycolysis is crucial during the activation and differentiation of $\mathrm{T}$ cells in the periphery. Thus, limiting glucose availability in activating $\mathrm{T}$ cells compromises TCR induced growth and proliferation and also the expression of certain effector molecules such as interferon $\gamma$ (IFN $\gamma$; Cham et al., 2008; Jacobs et al., 2008). The transcription factor c-Myc is crucial for the metabolic switch in glucose metabolism that accompanies the activation of naïve T cells (Wang et al., 2011). Accordingly, deletion of c-Myc in naïve $\mathrm{T}$ cells prevents TCR induced glucose uptake and glycolysis, and activated c-Myc-null T cells completely fail to grow or proliferate (Trumpp et al., 2001; Iritani et al., 2002; Dose et al., 2006; Wang et al., 2011). Is PI3K and Akt signaling also required for the increase in glucose uptake and glycolysis in TCR activated T cells in the periphery? Certainly, antigen receptor induced c-Myc expression and glucose uptake have been attributed to PI3K signaling (Frauwirth et al., 2002; Grumont etal., 2002; Doughty et al., 2006; Jacobs et al., 2008; Wang et al., 2011). However, one criticism of these studies is that they rely on experiments involving the overexpression of Akt and the use of the PI3K inhibitor LY294002. Overexpression studies can be difficult to interrupt and while LY294002 was initially believed to be a highly specific PI3K inhibitor, and as such was used in good faith, it has since emerged that this inhibitor is rather non-specific. LY294002 potently inhibits a number kinases other than PI3K, including those with described roles in regulating $\mathrm{T}$ cell growth and proliferation, i.e., mTORC1 and Pim family kinases (Brunn et al., 1996; Davies et al., 2000; Fox et al., 2005b; Bain et al., 2007). The importance of these other LY204002 targets for $\mathrm{T}$ cell metabolism can be appreciated by a comparison of the cellular sizes of PI3K/Akt deficient CD8 cytotoxic T lymphocytes (CTL) and wild-type CTL cultured in the presence of LY294002. While PI3K/Akt deficient CTL are comparable in size to wild-type CTL, LY294002-treated CTL are substantially smaller (Cornish et al., 2006; Sinclair et al., 2008; Macintyre et al., 2011). Therefore, the question as to whether PI3K regulates TCR induced c-Myc expression has not been satisfactorily investigated to date. Nevertheless, a comparison of PI3K/Akt and c-Myc deficient T cells is extremely informative. In contrast to the failure of c-Mycnull T cells to engage in TCR stimulated growth and proliferation, PI3K deficient $\mathrm{T}$ cells show a relatively mild defect in growth and proliferation with activated $\mathrm{T}$ cells capable of completing numerous divisions, though at a reduced rate (Okkenhaug et al., 2002, 2006). Furthermore, T cells expressing a PDK1 K465E mutant which have defective TCR stimulated Akt activity, undergo normal TCR induced growth and proliferation (Waugh et al., 2009). These observations coupled to the fact that $\mathrm{T}$ cells activated in limiting concentrations of glucose do show a marked defect in proliferation argue that TCR induced c-Myc expression, glucose uptake and glycolysis is not compromised by disruption of PI3K and Akt signaling (Jacobs et al., 2008). More recently, PI3K/Akt independent glucose uptake and glycolysis in TCR activated T cells has been confirmed using pharmacological inhibitors of PI3K $\delta$ (IC87114) and Akt (Akti1/2) with substantially greater selectivity than LY294002 (Macintyre et al., 2011). Aktil/2 is particularly selective toward Akt due to its unique allosteric mechanism of inhibition, binding to the $\mathrm{PH}$ domain of Akt and preventing the $\mathrm{PH}$ domain- $\mathrm{PI}(3,4,5) \mathrm{P}_{3}$ interaction and the resultant conformational change that is a prerequisite for Akt activation (Zhao et al., 2005; Bain et al., 2007). Both IC87114 and Akti1/2 prevent PI3K/Akt signaling in T cells while having no effect on TCR induced glucose uptake (Macintyre et al., 2011). Therefore, it seems clear that PI3K has differential roles in regulating glucose metabolism in developing thymocytes in the thymus and mature $\mathrm{T}$ cells in the periphery.

Once activated, T cells differentiate into various different effector T cell subsets depending on the local environment and cytokine availability. Many of these effector T cell subsets maintain an elevated glycolytic rate in response to cytokine signaling (Macintyre et al., 2011; Shi et al., 2011). For example, activated CD8 T cells undergo rapid growth and proliferation in response to interleukin 2 (IL2) as they differentiate into functional CTL. In response to IL2 signaling CTL maintain high levels of glucose uptake and lactate production indicative of elevated glycolysis (Macintyre et al., 2011). IL2 also promotes glucose uptake and glycolysis independently of PI3K and Akt but a key role has been revealed for PDK1. Thus, while IC87114 and Akti1/2 have no effect on CTL glucose uptake, a pronounced decrease is observed following the deletion of PDK1 using a Cre/loxP strategy (Macintyre et al., 2011). While $\mathrm{PDK} 1$ is responsible for the activation of Akt, it also activates a number of other members of the AGC kinase family including protein kinase C (PKC), 70-kDa ribosomal S6 kinase (p70S6K), 90-kDa ribosomal S6 kinase (p90RSK), and serum/glucocorticoid regulated kinase (SGK; Pearce et al., 2010). However, unlike the activation of Akt, PDK1 mediated activation of these other AGC family members are independent of PI3K signaling (Figure 1C). As members of this kinase family have overlapping substrate specificity it is likely that PDK1 dependent, Akt independent 
regulation of glucose metabolism reflects functional redundancy within the AGC family of protein kinases (Brunet et al., 2001; Zhang et al., 2006; Sapkota et al., 2007).

mTORC1 has described roles in regulating various aspects of cellular metabolism and given that its activity is independent of PI3K and Akt in some activated $\mathrm{T}$ cell subsets, it remains likely that mTORC1 is involved in maintaining glucose uptake and glycolysis (unpublished data; Duvel et al., 2010; Macintyre et al., 2011). Indeed, inhibition of mTORC1 decreases glycolysis in T cells activated under Th17 polarizing conditions (Shi et al., 2011). However, as mTORC1 inhibition also disrupts Th17 differentiation, it is difficult to interpret whether the effect of rapamycin on glycolysis is direct or as a result of the differentiation of different $\mathrm{T}$ cells. Therefore, a role for $\mathrm{mTORC} 1$ in controlling glycolysis in $\mathrm{T}$ cells has still to be formally demonstrated.

\section{T CELL MIGRATION AND METABOLISM}

The expression of adhesion molecules and chemokine receptors orchestrate the peripheral trafficking of activated $\mathrm{T}$ cells. The p110 $\gamma$ catalytic subunit is the major PI3K isoform in T cells that promotes $\mathrm{PI}(3,4,5) \mathrm{P}_{3}$ signaling in response to chemokines. Thus, migration to a range of chemokines is deficient in $\mathrm{p} 110 \gamma^{-/-} \mathrm{T}$ cells and these $\mathrm{T}$ cells fail to traffic normally to sites of inflammation (Reif et al., 2004; Smith et al., 2007; Martin et al., 2008; Thomas et al., 2008). T cell migration and motility are energy demanding processes and it is tempting to speculate that chemokine receptor signaling might promote $\mathrm{T}$ cell glucose metabolism to meet these energy demands. However, while there is some tentative data linking chemokine receptor signaling to cell growth and metabolism in transformed $\mathrm{T}$ cells and developing thymocytes the relationship between chemokine receptor signaling and $\mathrm{T}$ cell metabolism has not been directly studied (Janas et al., 2010; Lo et al., 2010). Nonetheless, it is worth mentioning that factors that influence $\mathrm{T}$ cell migration and/or homing, and thus the peripheral tissue destination of $\mathrm{T}$ cells, will affect $\mathrm{T}$ cell metabolism, albeit indirectly, by determining the cytokine environment to which

\section{REFERENCES}

Alessi, D. R., and Cohen, P. (1998). Mechanism of activation and function of protein kinase B. Curr. Opin. Genet. Dev. 8, 55-62.

Bain, J., Plater, L., Elliott, M., Shpiro, N., Hastie, C. J., McLauchlan, H., Klevernic, I., Arthur, J. S., Alessi, D. R., and Cohen, P. (2007). The selectivity of protein kinase inhibitors: a further update. Biochem. J. 408, 297-315.

Bayascas, J. R., Wullschleger, S., Sakamoto, K., Garcia-Martinez, J. M., Clacher, C., Komander, D., van Aalten, D. M. F., Boini, K. M., Lang, F., Lipina, C., Logie, L., Sutherland, C., Chudek, J. A., van Diepen, J. A., Voshol, P. J., Lucocq, J. M., and Alessi, D. R. (2008). Mutation of the PDK1 PH domain inhibits protein kinase B/Akt, leading to small size and insulin resistance. Mol. Cell. Biol. 28, 3258-3272.
Brand, K., Williams, J. F., and Weidemann, M. J. (1984). Glucose and glutamine metabolism in rat thymocytes. Biochem. J. 221, 471-475.

Brunet, A., Park, J., Tran, H., Hu, L. S., Hemmings, B. A., and Greenberg, M. E. (2001). Protein kinase SGK mediates survival signals by phosphorylating the forkhead transcription factor FKHRL1 (FOXO3a). Mol. Cell. Biol. 21, 952-965.

Brunn, G. J., Williams, J., Sabers, C., Wiederrecht, G., Lawrence, J. C., and Abraham, R. T. (1996). Direct inhibition of the signaling functions of the mammalian target of rapamycin by the phosphoinositide 3-kinase inhibitors, wortmannin and LY294002. EMBO J. 15, 52565267.

Burgering, B. M. T. (2008). A brief introduction to FOXOlogy. Oncogene 27, 2258-2262.

they are exposed. A comparison of activated $\mathrm{T}$ cells responding to related cytokines IL2 and IL15 illustrates the differential regulation of T cell metabolism by distinct cytokine environments. IL2 promotes elevated glucose metabolism and glycolysis while IL15 does not maintain this metabolic state and T cells responding to IL15 are smaller with reduced nutrient uptake and glycolysis (Cornish et al., 2006; Macintyre et al., 2011; unpublished data). While PI3K $\gamma$ controls $\mathrm{T}$ cell migration in response to chemokines, PI3K $\delta$ regulates the repertoire of adhesion and chemokine receptors expressed by activated T cells. PI $3 \mathrm{~K} \delta$, signaling through Akt and the Foxo transcription factors, regulates the expression of key molecules required for $\mathrm{T}$ cell homing between the blood and the lymphoid organs; the adhesion molecule CD62L (also called L-selectin) and the chemokine receptors CC-chemokine receptor 7 (CCR7) and sphingosine-1-phosphate receptor $1\left(\mathrm{~S}_{1} \mathrm{P}_{1}\right)$. Disruption of $\mathrm{PI} 3 \mathrm{~K} \delta / \mathrm{Akt}$ signaling in activated $\mathrm{CD} 8 \mathrm{~T}$ cells prevents the down-regulation of CD62L, CCR7, and $\mathrm{S}_{1} \mathrm{P}_{1}$ and these $\mathrm{T}$ cells retain a lymph node trafficking pattern rather than migrating to non-lymphoid tissues and the sites of inflammation (Sinclair et al., 2008; Waugh et al., 2009; Finlay and Cantrell, 2010; Macintyre etal., 2011). Thus, PI3K $\delta$ deficient T cells activated in vivo or wild-type $\mathrm{T}$ cells activated in mice treated with a PI3K $\delta$ inhibitor fail to traffic into the periphery to antigenic sites (Jarmin et al., 2008). Therefore, both PI3K $\gamma$ and $\delta$ isoforms coordinately regulate $\mathrm{T}$ cell peripheral tissue homing thereby dictating the cytokine environments encountered and indirectly impacting upon $\mathrm{T}$ cell metabolism.

\section{FINAL REMARK}

It has recently become clear that the PI3K/Akt signaling axis is not the important regulator of glucose uptake and glycolysis in mature $\mathrm{T}$ cells, as initially described. However, disrupting PI3K may in fact impact upon $\mathrm{T}$ cell metabolism through indirect mechanisms, i.e., through altering their in vivo trafficking pattern, which will dictate the cytokines these $\mathrm{T}$ cells encounter.

Calleja, V., Alcor, D., Laguerre, M., Park, J., Vojnovic, B., Hemmings, B. A., Downward, J., Parker, P. J., and Larijani, B. (2007). Intramolecular and intermolecular interactions of protein kinase $B$ define its activation in vivo. PLoS Biol. 5, e95. doi: 10.1371/journal.pbio.0050095

Cameron, A. J., De Rycker, M., Calleja, V., Alcor, D., Kjaer, S., Kostelecky, B., Saurin, A., Faisal, A., Laguerre, M., Hemmings, B. A., McDonald, N., Larijani, B., and Parker, P. J. (2007). Protein kinases, from B to C. Biochem. Soc. Trans. 35, 1013-1017. Cham, C. M., Driessens, G., O'Keefe, J. P., and Gajewski, T. F. (2008). Glucose deprivation inhibits multiple key gene expression events and effector functions in CD8 + T cells. Eur. J. Immunol. 38, 2438-2450.

Ciofani, M., and Zuniga-Pflucker, J. C. (2005). Notch promotes survival of pre- $\mathrm{T}$ cells at the beta-selection checkpoint by regulating cellular metabolism. Nat. Immunol. 6, 881888.

Coffer, P. J., and Burgering, B. M. (2004). Forkhead-box transcription factors and their role in the immune system. Nat. Rev. Immunol. 4, 889-899.

Cornish, G. H., Sinclair, L. V., and Cantrell, D. A. (2006). Differential regulation of $\mathrm{T}$-cell growth by IL-2 and IL-15. Blood 108, 600-608.

Costello, P. S., Gallagher, M., and Cantrell, D. A. (2002). Sustained and dynamic inositol lipid metabolism inside and outside the immunological synapse. Nat. Immunol. 3, 10821089.

Davies, S. P., Reddy, H., Caivano, M., and Cohen, P. (2000). Specificity and mechanism of action of some commonly used protein kinase inhibitors. Biochem. J. 351, 95-105. 
Delgoffe, G. M., and Powell, J. D. (2009). mTOR: taking cues from the immune microenvironment. Immunology 127, 459-465.

Dose, M., Khan, I., Guo, Z., Kovalovsky, D., Krueger, A., von Boehmer, H., Khazaie, K., and Gounari, F (2006). c-Myc mediates pre-TCRinduced proliferation but not developmental progression. Blood 108, 2669-2677.

Doughty, C. A., Bleiman, B. F., Wagner, D. J., Dufort, F. J., Mataraza, J. M., Roberts, M. F., and Chiles, T. C. (2006). Antigen receptor-mediated changes in glucose metabolism in B lymphocytes: role of phosphatidylinositol 3-kinase signaling in the glycolytic control of growth. Blood 107, 4458-4465.

Duvel, K., Yecies, J. L., Menon, S., Raman, P., Lipovsky, A. I., Souza, A. L., Triantafellow, E., Ma, Q., Gorski, R., Cleaver, S., Vander Heiden, M. G., MacKeigan, J. P., Finan, P. M., Clish, C. B., Murphy, L. O., and Manning, B. D. (2010). Activation of a metabolic gene regulatory network downstream of mTOR complex 1. Mol. Cell 39, 171-183.

Fayard, E., Gill, J., Paolino, M., Hynx, D., Hollander, G. A., and Hemmings, B. A. (2007). Deletion of PKBalpha/Akt1 affects thymic development. PLoS ONE 2, e992. doi: 10.1371/journal.pone.0000992

Finlay, D., and Cantrell, D. (2010). Phosphoinositide 3-kinase and the mammalian target of rapamycin pathways control $\mathrm{T}$ cell migration. Ann. N. Y. Acad. Sci. 1183 , 149-157.

Finlay, D. K., Kelly, A. P., Clarke, R., Sinclair, L. V., Deak, M., Alessi, D. R., and Cantrell, D. A. (2010). Temporal differences in the dependency on phosphoinositide-dependent kinase 1 distinguish the development of invariant Valphal4 NKT cells and conventional T cells. J. Immunol. 185 , 5973-5982.

Finlay, D. K., Sinclair, L. V., Feijoo, C., Waugh, C. M., Hagenbeek, T. J., Spits, H., and Cantrell, D. A. (2009). Phosphoinositide-dependent kinase 1 controls migration and malignant transformation but not cell growth and proliferation in PTEN-null lymphocytes. J. Exp. Med. 206, 24412454.

Fox, C. J., Hammerman, P. S., and Thompson, C. B. (2005a). Fuel feeds function: energy metabolism and the T-cell response. Nat. Rev. Immunol. $5,844-852$.

Fox, C. J., Hammerman, P. S., and Thompson, C. B. (2005b). The Pim kinases control rapamycin-resistant
T cell survival and activation. J. Exp. Med. 201, 259-266.

Frauwirth, K. A., Riley, J. L., Harris, M. H., Parry, R. V., Rathmell, J. C., Plas, D. R., Elstrom, R. L., June, C. H., and Thompson, C. B. (2002). The CD28 signaling pathway regulates glucose metabolism. Immunity 16 , 769-777.

Garcon, F., Patton, D. T., Emery, J. L., Hirsch, E., Rottapel, R., Sasaki, T., and Okkenhaug, K. (2007). CD28 provides T-cell costimulation and enhances PI3K activity at the immune synapse independently of its capacity to interact with the p85/p110 heterodimer. Blood 111, 1464-1471.

Greiner, E. F., Guppy, M., and Brand, K. (1994). Glucose is essential for proliferation and the glycolytic enzyme induction that provokes a transition to glycolytic energy production. $J$. Biol. Chem. 269, 31484-31490.

Grumont, R. J., Strasser, A., and Gerondakis, S. (2002). B cell growth is controlled by phosphatidylinosotol 3-kinase-dependent induction of Rel/NF-kappaB regulated c-myc transcription. Mol. Cell 10, 12831294.

Hagenbeek, T. J., and Spits, H. (2008) T-cell lymphomas in T-cell-specific Pten-deficient mice originate in the thymus. Leukemia 22, 608-619.

Hanada, M., Feng, J., and Hemmings, B. A. (2004). Structure, regulation and function of PKB/AKT - a major therapeutic target. Biochim. Biophys. Acta 1697, 3-16.

Harriague, J., and Bismuth, G. (2002). Imaging antigen-induced PI3K activation in T cells. Nat. Immunol. 3 , 1090-1096.

Hinton, H. J., Alessi, D. R., and Cantrell, D. A. (2004). The serine kinase phosphoinositide-dependent kinase 1 (PDK1) regulates $\mathrm{T}$ cell development. Nat. Immunol. 5, 539-545.

Huppa, J. B., Gleimer, M., Sumen, C., and Davis, M. M. (2003). Continuous $\mathrm{T}$ cell receptor signaling required for synapse maintenance and full effector potential. Nat. Immunol. 4, 749-755. Iritani, B. M., Delrow, J., Grandori, C., Gomez, I., Klacking, M., Carlos, L. S., and Eisenman, R. N. (2002). Modulation of T-lymphocyte development, growth and cell size by the Myc antagonist and transcriptional repressor Mad1. EMBO J. 21, 4820-4830.

Jacobs, S. R., Herman, C. E., Maciver, N. J., Wofford, J. A., Wieman, H. L., Hammen, J. J., and Rathmell, J. C. (2008). Glucose uptake is limiting in $\mathrm{T}$ cell activation and requires CD28-mediated Akt-dependent and independent pathways. J. Immunol. 180, 4476-4486.
Janas, M. L., Varano, G., Gudmundsson, K., Noda, M., Nagasawa, T., and Turner, M. (2010). Thymic development beyond beta-selection requires phosphatidylinositol 3-kinase activation by CXCR4. J. Exp. Med. 207, 247-261.

Jarmin, S. J., David, R., Ma, L., Chai, J. G., Dewchand, H., Takesono, A. Ridley, A. J., Okkenhaug, K., and Marelli-Berg, F. M. (2008). T cell receptor-induced phosphoinositide3-kinase p110delta activity is required for $\mathrm{T}$ cell localization to antigenic tissue in mice. J. Clin. Invest. 118, 1154-1164.

Ji, H., Rintelen, F., Waltzinger, C., Bertschy Meier, D., Bilancio, A., Pearce, W., Hirsch, E., Wymann, M. P., Ruckle, T., Camps, M., Vanhaesebroeck, B., Okkenhaug, K., and Rommel, C. (2007). Inactivation of PI3Kgamma and PI3Kdelta distort T-cell development and causes multiple organ inflammation. Blood 110, 2940-2947.

Juntilla, M. M., Wofford, J. A., Birnbaum, M. J., Rathmell, J. C., and Koretzky, G. A. (2007). Aktl and Akt2 are required for alphabeta thy mocyte survival and differentiation. Proc. Natl. Acad. Sci. U.S.A. 104 12105-12110.

Kelly, A. P., Finlay, D. K., Hinton, H. J., Clarke, R. G., Fiorini, E., Radtke, F., and Cantrell, D. A. (2007). Notchinduced $\mathrm{T}$ cell development requires phosphoinositide-dependent kinase 1. EMBO J. 26, 3441-3450.

Koyasu, S. (2003). The role of PI3K in immune cells. Nat. Immunol. 4 , 313-319.

Laplante, M., and Sabatini, D. M. (2009). mTOR signaling at a glance. J. Cell. Sci. 122, 3589-3594.

Lo, B. K., Yu, M., Zloty, D., Cowan, B., Shapiro, J., and McElwee, K. J. (2010). CXCR3/ligands are significantly involved in the tumorigenesis of basal cell carcinomas. Am. J. Pathol. 176, 2435-2446.

Macintyre, A. N., Finlay, D., Preston, G., Sinclair, L. V., Waugh, C. M., Tamas, P., Feijoo, C., Okkenhaug, K., and Cantrell, D. A. (2011). Protein kinase B controls transcriptional programs that direct cytotoxic $\mathrm{T}$ cell fate but is dispensable for $\mathrm{T}$ cell metabolism. Immunity 34, 224-236.

Manning, B. D., and Cantley, L. C. (2007). AKT/PKB signaling: navigating downstream. Cell 129, $1261-$ 1274.

Mao, C., Tili, E. G., Dose, M., Haks, M. C., Bear, S. E., Maroulakou, I., Horie, K., Gaitanaris, G. A., Fidanza, V., Ludwig, T., Wiest, D. L., Gounari, F., and Tsichlis, P. N. (2007). Unequal contribution of Akt isoforms in the double-negative to double-positive thymocyte transition. J. Immunol. 178, 5443-5453.

Marko, A. J., Miller, R. A., Kelman, A., and Frauwirth, K. A. (2010). Induction of glucose metabolism in stimulated $\mathrm{T}$ lymphocytes is regulated by mitogen-activated protein kinase signaling. PLoS ONE 5, e15425. doi: 10.1371/journal.pone.0015425

Martin, A. L., Schwartz, M. D., Jameson, S. C., and Shimizu, Y. (2008). Selective regulation of CD8 effector $\mathrm{T}$ cell migration by the $\mathrm{p} 110$ gamma isoform of phosphatidylinositol 3kinase. J. Immunol. 180, 2081-2088.

Okkenhaug, K., Bilancio, A., Farjot, G., Priddle, H., Sancho, S., Peskett, E., Pearce, W., Meek, S. E., Salpekar, A., Waterfield, M. D., Smith, A. J., and Vanhaesebroeck, B. (2002). Impaired B and T cell antigen receptor signaling in p110delta PI 3-kinase mutant mice. Science 297, 1031-1034.

Okkenhaug, K., Patton, D. T., Bilancio, A., Garcon, F., Rowan, W. C., and Vanhaesebroeck, B. (2006). The p110delta isoform of phosphoinositide 3-kinase controls clonal expansion and differentiation of Th cells. J. Immunol. 177, 5122-5128.

Okkenhaug, K., and Vanhaesebroeck, B. (2003). PI3K in lymphocyte development, differentiation and activation. Nat. Rev. Immunol. 3, 317-330.

Pearce, L. R., Komander, D., and Alessi, D. R. (2010). The nuts and bolts of AGC protein kinases. Nat. Rev. Mol. Cell Biol. 11, 9-22.

Reif, K., Okkenhaug, K., Sasaki, T., Penninger, J. M., Vanhaesebroeck, B., and Cyster, J. G. (2004). Cutting edge: differential roles for phosphoinositide 3-kinases, p110gamma and p110delta, in lymphocyte chemotaxis and homing. J. Immunol. 173, 2236-2240.

Sapkota, G. P., Cummings, L., Newell, F. S., Armstrong, C., Bain, J., Frodin, M., Grauert, M., Hoffmann, M., Schnapp, G., Steegmaier, M., Cohen, P., and Alessi, D. R. (2007). BI-D1870 is a specific inhibitor of the p90 RSK (ribosomal S6 kinase) isoforms in vitro and in vivo. Biochem. J. 401, 29-38.

Sasaki, T., Irie-Sasaki, J., Jones, R. G., Oliveira-dos-Santos, A. J., Stanford, W. L., Bolon, B., Wakeham, A., Itie, A., Bouchard, D., Kozieradzki, I., Joza, N., Mak, T. W., Ohashi, P. S., Suzuki, A., and Penninger, J. M. (2000). Function of PI3Kgamma in thymocyte development, $\mathrm{T}$ cell activation, and neutrophil migration. Science 287, 1040-1046. 
Shi, L. Z., Wang, R., Huang, G., Vogel, P., Neale, G., Green, D. R., and Chi, H. (2011). HIFlalphadependent glycolytic pathway orchestrates a metabolic checkpoint for the differentiation of $\mathrm{TH} 17$ and Treg cells. J. Exp. Med. 208, 1367-1376.

Sinclair, L. V., Finlay, D., Feijoo, C., Cornish, G. H., Gray, A., Ager, A., Okkenhaug, K., Hagenbeek, T. J., Spits, H., and Cantrell, D. A. (2008). Phosphatidylinositol3-OH kinase and nutrient-sensing mTOR pathways control T lymphocyte trafficking. Nat. Immunol. 9, 513-521.

Smith, L. D., Hickman, E. S., Parry, R. V., Westwick, J., and Ward, S. G. (2007). PI3Kgamma is the dominant isoform involved in migratory responses of human $\mathrm{T}$ lymphocytes: effects of ex vivo maintenance and limitations of non-viral delivery of siRNA. Cell. Signal. 19, 2528-2539.

Suzuki, A., Yamaguchi, M. T., Ohteki, T., Sasaki, T., Kaisho, T., Kimura, Y., Yoshida, R., Wakeham, A., Higuchi, T., Fukumoto, M., Tsubata, T., Ohashi, P. S., Koyasu, S., Penninger, J. M., Nakano, T., and Mak, T. W. (2001). T cell-specific loss of Pten leads to defects in central and peripheral tolerance. Immunity 14 , 523-534.
Swat, W., Montgrain, V., Doggett, T. A., Douangpanya, J., Puri, K., Vermi, W., and Diacovo, T. G. (2006). Essential role of PI3Kdelta and PI3Kgamma in thymocyte survival. Blood 107, 2415-2422.

Thomas, M. S., Mitchell, J. S., DeNucci, C. C., Martin, A. L., and Shimizu, Y. (2008). The pl10gamma isoform of phosphatidylinositol 3-kinase regulates migration of effector CD4 T lymphocytes into peripheral inflammatory sites. J. Leukoc. Biol. 84, 814-823.

Trumpp, A., Refaeli, Y., Oskarsson, T., Gasser, S., Murphy, M., Martin, G. R., and Bishop, J. M. (2001). c-Myc regulates mammalian body size by controlling cell number but not cell size. Nature 414, 768-773.

Vander Heiden, M. G., Cantley, L. C., and Thompson, C. B. (2009). Understanding the Warburg effect: the metabolic requirements of cell proliferation. Science 324, 1029-1033.

Vanhaesebroeck, B., GuillermetGuibert, J., Graupera, M., and Bilanges, B. (2010). The emerging mechanisms of isoform-specific PI3K signalling. Nat. Rev. Mol. Cell Biol. 11, 329-341.

Wang, R., Dillon, C. P., Shi, L. Z., Milasta, S., Carter, R., Finkelstein, D., McCormick, L. L., Fitzgerald, P., Chi, H., Munger, J., and Green, D. R. (2011). The transcription factor Myc controls metabolic reprogramming upon $\mathrm{T}$ lymphocyte activation. Immunity 35 , 871-882.

Waugh, C., Sinclair, L., Finlay, D. Bayascas, J. R., and Cantrell, D. (2009). Phosphoinositide (3,4,5)-triphosphate binding to phosphoinositide-dependent kinase 1 regulates a protein kinase B/Akt signaling threshold that dictates T-cell migration, not proliferation. Mol. Cell. Biol. 29, 5952-5962.

Webb, L. M., Vigorito, E., Wymann, M. P., Hirsch, E., and Turner, M (2005). Cutting edge: T cell development requires the combined activities of the p1l0gamma and p110delta catalytic isoforms of phosphatidylinositol 3-kinase. J. Immunol. 175, 2783-2787.

Wofford, J. A., Wieman, H. L., Jacobs, S. R., Zhao, Y., and Rathmell, J. C. (2008). IL-7 promotes Glutl trafficking and glucose uptake via STAT5mediated activation of Akt to support T-cell survival. Blood 111, 21012111.

Zhang, H. H., Lipovsky, A. I., Dibble, C. C., Sahin, M., and Manning, B. D. (2006). S6K1 regulates GSK3 under conditions of mTORdependent feedback inhibition of Akt. Mol. Cell 24, 185-197.

Zhao, Z., Leister, W. H., Robinson, R. G., Barnett, S. F., Defeo-Jones, D.,
Jones, R. E., Hartman, G. D., Huff, J R., Huber, H. E., Duggan, M. E., and Lindsley, C. W. (2005). Discovery of 2,3,5-trisubstituted pyridine derivatives as potent Akt1 and Akt2 dual inhibitors. Bioorg. Med. Chem. Lett. 15, 905-909.

Conflict of Interest Statement: The author declares that the research was conducted in the absence of any commercial or financial relationships that could be construed as a potential conflict of interest.

Received: 01 June 2012; paper pending published: 13 June 2012; accepted: 24 July 2012; published online: 07 August 2012.

Citation: Finlay DK (2012) Regulation of glucose metabolism in $T$ cells: new insight into the role of phosphoinositide 3-kinases. Front. Immun. 3:247. doi: 10.3389/fimmu.2012.00247

This article was submitted to Frontiers in $T$ Cell Biology, a specialty of Frontiers in Immunology.

Copyright $(\odot 2012$ Finlay. This is an openaccess article distributed under the terms of the Creative Commons Attribution License, which permits use, distribution and reproduction in other forums, provided the original authors and source are credited and subject to any copyright notices concerning any third-party graphics etc. 